\title{
Research
}

\section{Reconciling Social and Biological Needs in an Endangered Ecosystem: the Palouse as a Model for Bioregional Planning}

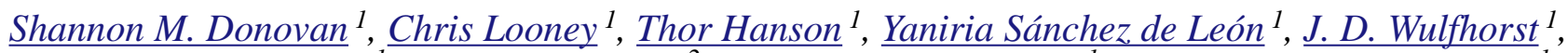 \\ Sanford D. Eigenbrode $^{1}$, Michael Jennings $^{2}$, Jodi Johnson-Maynard ${ }^{1}$, and Nilsa A. Bosque Pérez ${ }^{1}$
}

\begin{abstract}
The Palouse region of southeastern Washington State and an adjacent portion of northern Idaho is a working landscape dominated by agricultural production, with less than $1 \%$ of the original bunchgrass prairie remaining. Government agencies and conservation groups have begun efforts to conserve Palouse prairie remnants, but they lack critical information about attitudes and perceptions among local landowners toward biological conservation. Knowledge about the location and condition of native biological communities also remains sparse. Using a bioregional approach, we integrated data collected through biological surveys and social interviews to investigate relationships between biologically and socially meaningful aspects of the landscape. We combined GIS layers of participant-identified meaningful places with maps of native biological communities to identify the overlap between these data sets. We used these maps and interview narratives to interpret how stakeholder perceptions of the landscape corresponded with patterns of native biodiversity. We found several prominent landscape features on the Palouse that supported diverse biological communities and were important to stakeholders for multiple reasons. These places may be expedient focal points for conservation efforts. However, the many small prairie remnants on the Palouse, although ecologically important, were mostly unidentified by participants in this study and thus warrant a different conservation approach. These findings will assist government agencies and conservation groups in crafting conservation strategies that consider stakeholder perceptions and their connection with the Palouse landscape. This study also demonstrates how GIS tools can link biological and social data sets to aid conservation efforts on private land.
\end{abstract}

Key Words: landscape; participatory research; spatial mapping; biodiversity; conservation; private lands

\section{INTRODUCTION}

The Palouse Prairie of southeastern Washington State and adjacent northern Idaho is a critically endangered ecosystem (Noss et al. 1995). Black et al. (2000) estimate that less than $1 \%$ of the native grasslands remain, primarily as small patches located on private lands. Now surrounded by an agriculturally dominated landscape, these prairie remnants are threatened by rural residential development and the spread of invasive species (Lichthardt and Moseley 1997). Active conservation and management are critical to maintaining or potentially restoring prairie remnants. However, no regional or local policies currently exist to promote Palouse Prairie conservation, and those who believe such policies to be inconsistent with private landowner rights object to even discussing them.
Both policy makers and local NGOs have begun to explore protection mechanisms for the remaining native prairie remnants of the Palouse. However, identifying regionally appropriate and acceptable policies that simultaneously maintain prime farmland, protect private landowner rights, provide opportunities for growth, and conserve endangered biological communities has proven difficult. Limited information has hampered efforts to locate native biological communities and identify landowner and stakeholder values and beliefs regarding the Palouse landscape (Latah County Planning and Zoning Commission 2004). Conservation plans that consider social values and human perceptions regarding biodiversity will likely receive more support from stakeholders than those developed based solely on biological value (Thayer 2003). To gain a better understanding of 
relationships between biodiversity conservation and human perceptions of the Palouse, we addressed the following questions:

- What are the socially important places located within the Palouse landscape?

- What characteristics of those places make them socially important?

- How are native plant and invertebrate communities distributed on the Palouse?

- What spatial overlaps exist between locations with high native biodiversity, i.e., potential targets for conservation efforts, and those deemed worthy of preservation based on socially important characteristics?

- What conservation strategies are suggested by the existence of such overlaps?

We sought answers to these questions using an interdisciplinary approach in which we collaboratively designed the research and collected the data, and then coordinated and integrated the analyses and interpretations among several disciplines. This paper presents a product of that collaboration in which we use a spatially explicit method to examine relationships between our data on human $\mathrm{s}$ perceptions and biological diversity within the Palouse landscape. Our results have implications for planners and policy makers given that Palouse Prairie remnants are important to landowners and the local community for reasons in addition to or despite their biological diversity.

\section{Bioregional planning and landscape conservation}

The roots of the bioregional approach lie in early efforts to combine human and ecological needs in land-use planning (McHarg 1969). Place-specific planning that considers frequently inter-related social, physical, and biological components of a region is necessary to achieve landscape-level conservation goals (Steiner 1991, Bailey 2003, Thayer 2003). Many traditional planning efforts use a top-down approach with little opportunity for public involvement, which is often limited to public hearings on already drafted zoning regulations. Historically, holistic planning efforts may have been hampered because of a lack of resources or an inability to combine and present social and biophysical data meaningfully (McHarg 1969). In contrast, contemporary place-specific planning frameworks tend to be more flexible and strive for greater inclusion of local stakeholder views and values (Thayer 2003). Bioregionalism is a placespecific perspective designed to achieve sustainable resource use and biodiversity conservation by simultaneously considering "natural" ecological boundaries and perceptions held by local stakeholders (Thayer 2003). Including stakeholder perspectives during planning processes can increase acceptance of regional plans because the finished products inherently reflect the varied stakeholder relationships with the landscape (Theobald and Hobbs 1998, 2002, Wondolleck and Yaffee 2000). Bioregional planning explicitly integrates biophysical and social information, focusing on ecosystems rather than political boundaries as the units of analysis (Herring 1999), and can address the unique complexity embedded in contemporary working landscapes with regard to issues such as production, conflicts over rural residential development, and invasive species.

Identification of spatial connections and overlap between native biota, cultural attitudes, and resource use zones is critical to identifying conservation options in a landscape such as the Palouse (Boothby 2000, Farina 2000). Humans give meaning to the natural environment by using symbols and concepts from their social worlds, in effect transforming "spaces" into "places" (Greider and Garkovich 1994). Regional planning, therefore, can be thought of as managing the symbolic landscape to identify and protect meaningful places within it (Thayer 2003). Geographic information system (GIS) tools provide an opportunity to develop powerful approaches to making such spatially explicit linkages between biological and social information essential to bioregional planning. Recent studies have sought to develop such GISbased approaches (Siniscalchi et al. 2006, Brown and Raymond 2007, Alessa et al. 2008). In this paper we present a unique approach that uses GIS tools to combine quantitative biological data with qualitative data on the social importance of landscape elements. With this approach, we illustrate how social definitions of place overlap with areas of biological diversity. 


\section{Bioregionalism: reconciling biological and social needs on privately owned lands}

Understanding the range of landowner and stakeholder perspectives of landscape facilitates synergy between human needs and biodiversity conservation, reducing the potential for conflict in conservation planning (Russell and Harshbarger 2003). Private landowners often express concern for the environment (Norton 2000), but their support for conservation varies depending on perceived threats to their livelihood or private property rights (James 2002, Russell and Harshbarger 2003). Biodiversity conservation is often viewed with suspicion, fueled in part by legal conflicts arising from the implementation of federal environmental laws and policies (James 2002). When private land and private land rights dominate the social and physical landscape, a balance between individual rights and conservation goals is needed to plan for cultural and ecological sustainability (Riebsame 1998). Kemmis (1990) argues that, to reduce potential conflicts, environmental policy should be set within the context of the community and should reflect landowner and stakeholder values. Revealing place meanings can help policy and decision makers understand people's perspectives, providing the foundation for appropriate regional resource plans (Cheng et al. 2003). Conservation action in landscapes dominated by private ownership will depend on the decisions and attitudes of individual landowners and is promoted when social and environmental values converge (Luzar and Diagne 1999).

\section{The Palouse as a bioregion}

The Palouse covers approximately $16,000 \mathrm{~km}^{2}$, lying primarily within Whitman County, Washington, and Latah County, Idaho (Black et al. 2000). The region is characterized by a moderate climate and rolling hills formed from windblown Holocene loess (Orr and Orr 2002). These deep, fertile soils once supported a habitat mosaic of bunchgrass prairie interspersed with wetlands and forested ridges (Daubenmire 1942, Lichthardt and Moseley 1997, Black et al. 2000). Following thousands of years of use by Native Americans, European settlers harnessed this productive landscape for agriculture beginning in the 1870s and rapidly converted the land to cereal and cool-season legume production (Black et al. 2000). Agriculture remains a dominant economic, social, and biological force in the region, which produces some of the highest nonirrigated yields of wheat and legumes in the world (Scheuerman 2003).

Because of the expansion of agriculture, less than $1 \%$ of the native Palouse Prairie remains, making it among the most endangered ecosystems in the United States (Noss et al. 1995, Ricketts et al. 1997, Black et al. 2000). The few remaining patches of native vegetation contain plant associations and individual plant and animal species, including several endemics, that are rare or endangered at regional, national, and global scales (Noss et al. 1995, Lichthardt and Moseley 1997). The giant Palouse earthworm (Driloleirus americanus), for example, is a rare species last recorded on the Palouse over 20 years ago (Fender and McKeyFender 1990) and recently rediscovered at a prairie site surveyed during this project (Sánchez-de León and Johnson-Maynard 2008).

Although links between biological diversity and ecosystem function continue to be discovered, the scientific consensus is that loss of biological diversity alters ecosystem services and functions in ways that have immediate and long-term costs for human societies (reviewed in Hooper et al. 2005). There are several ecosystem functions on the Palouse that we expect are linked to prairie remnants and regional native biodiversity with immediate relevance to the rural and farming culture of the region, namely the importance of controlling introduced weeds and enhancing the effect of arthropod natural enemies.

Diverse native plant communities are more resistant to weed invasion and establishment than speciesdepleted communities (Blumenthal et al. 2003, Pokorny et al. 2005, Maron and Marler 2007), with long-term reductions in weed biomass seen at prairie restoration sites (Blumenthal et al. 2003). Plant diversity is particularly important, because both the presence of strong competitive species and species from multiple niches contribute to invasion resistance (Blumenthal et al. 2003, Fargione and Tilman 2005, Hooper et al. 2005).

The activity and effectiveness of natural enemies are higher in landscapes with more native habitat patches and other semiwild refuges (Marino and Landis 1996, Gurr et al. 2003, Thies et al. 2003). In fragmented ecosystems, the conservation of small habitat remnants is especially important for augmenting natural enemy populations, because 
species/area and species/isolation curves are steeper for parasitoids and predators than for herbivores and primary producers (Kruess and Tscharntke 2000, Steffan-Dewenter and Tscharntke 2002). Spatial arrangement is also more important for the former. Restoring prairie sites on the Palouse could enhance these services and functions, although the cost and uncertainty of restoration indicate that the conservation of existing remnants is a more desirable and economically attractive approach.

Threats to Palouse Prairie remnants include intentional destruction, the introduction of invasive species, and indirect effects associated with fragmentation and management practices in the surrounding matrix. Although we describe threats to Palouse Prairie remnants, these threats may also apply to other natural areas of the Palouse. Ongoing residential development, motorized recreational activities, and grazing can result in the destruction of entire remnants or areas within remnants (Lichthardt and Moseley 1997). Invasive species, among the most pervasive threats to prairie remnants (Lichthardt and Moseley 1997, Weddell and Lichthardt 1998), can be introduced from the surrounding agricultural matrix (Callaham and Blair 1991, McKone et al. 2001) by large herbivores (Laughlin 2003), recreational activities (Dickens et al. 2005), or other dispersal mechanisms. Indirect and less obvious threats to prairie remnants are related to changes in species composition because of fragmentation and edge effects (McKone et al. 2001), agrochemical drift, and nutrient enrichment from adjacent agricultural practices (Forsyth and Westcott 1994, Kleijn and Snoeijing 1997, Suding et al. 2005).

Most of the Palouse is privately owned, making landowner support essential to the successful implementation of conservation policies (Russell and Harshbarger 2003). Conservation challenges for the region extend beyond managing prairie remnants to include soil erosion, noxious weeds, and water quality, as well as the preservation of open space threatened by increasing residential development. Growing interest in conserving Palouse resources is exemplified by the expansion of regional conservation-focused nonprofit organizations as well as greater involvement by government agencies.

\section{METHODS}

\section{Study area}

Although many descriptions of the Palouse encompass a wider region (e.g., Caldwell 1961, Duffin 2005), we focused on a core area containing the majority of prairie remnants and most of the human population (Fig. 1). Local and regional policy makers expressed interest in this study, and its results are informing current landscape-level conservation planning efforts (Latah County Planning and Zoning Commission 2004).

\section{Methodological design}

\section{Land-cover data collection}

We created a land-cover map by hand-digitizing georeferenced National Agricultural Inventory Program imagery. The images were orthorectified aerial photographs of Latah and Whitman counties taken during 2004 and 2005, with a ground resolution of $1 \mathrm{~m}$. We assigned land-cover types (Table 1) to delineated polygons throughout our study area. Boundaries and cover types in the Palouse tend to be stark and easily identified in aerial imagery and were verified through site visits.

\section{Biological data collection}

We used biological survey data to create a GIS map of native species richness, i.e., the number of native species, based on land-cover and species occurrence data. Native species richness was determined for two taxa, butterflies (Hesperoidea and Papilionoidea) and vascular plants, which had been surveyed in four of the dominant land-cover types on the Palouse: forest, agriculture, prairie, and introduced perennial grasslands. Both groups have been frequently used as biodiversity indicators in environmental research (McGeoch 1998, Krauss et al. 2003), and are still relatively abundant on the Palouse compared to other groups such as mammals, fish, birds, or amphibians. Furthermore, native vascular plant communities define the Palouse prairie ecosystem (Daubenmire 1970) and include several species of conservation concern to Washington and Idaho as well as one federally listed species (Table 2). Although biodiversity can also include variability at genetic, species, and ecosystem levels (Gaston and Spicer 2004), species 
Fig. 1. Core study area and participatory mapping base map.

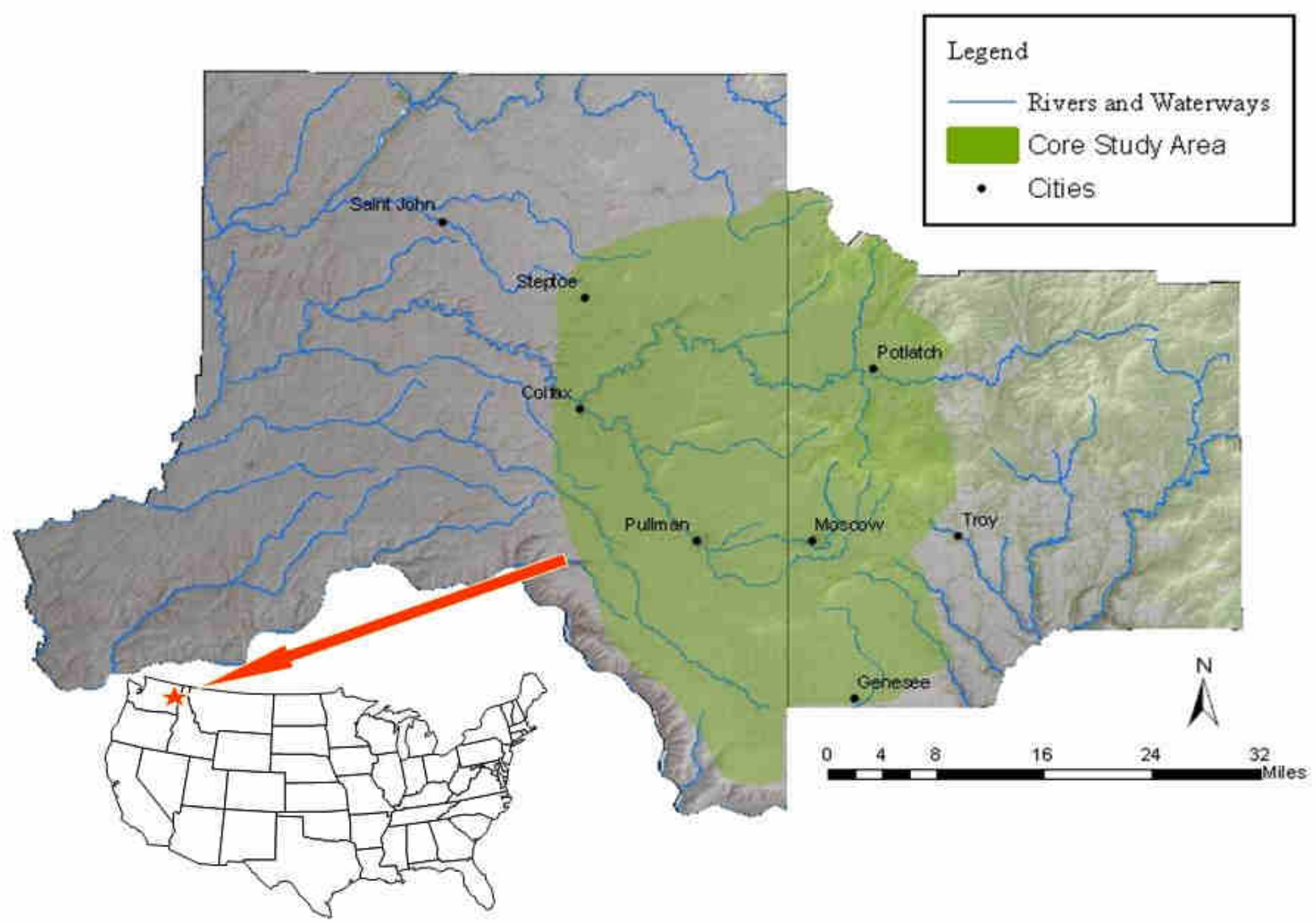

richness is conceptually simple and corresponds with available regional data.

Vascular plant data were collected using two different methods. Hanson et al. (2008) used randomly placed $20 \times 50 \mathrm{~cm}$ plots to sample prairie remnants and non-native perennial grasslands, whereas Pocewicz (2006) sampled forests, prairies, non-native perennial grasslands, and agricultural fields using 2 × 20 m transects. Pocewicz (2006) collected butterfly data using line-transect distance sampling (Buckland et al. 2004), in which individuals observed at all distances from a walked transect are recorded. We supplemented these data with Pollard transects (Pollard and Yates 1993), in which all butterflies observed within a 2 -m band on either side of a walked transect are recorded. The number and cover type of the sites sampled using each method are listed in Table 3 for both taxa.

Because threatened and endangered species are of particular concern to land management agencies and landowners, we also examined the distribution of four plant species of special conservation interest that are commonly described as Palouse prairie species (Table 2). We supplemented element occurrence data from the Washington Natural Heritage Program (WNHP) and Idaho Conservation 
Table 1. Land-cover classes and defining characteristics.

\begin{tabular}{|c|c|c|}
\hline Cover assignment & $\begin{array}{l}\text { Land-use/-cover } \\
\text { characteristics }\end{array}$ & Diagnostic features \\
\hline $\begin{array}{l}\text { Introduced perennial } \\
\text { grassland }\end{array}$ & $\begin{array}{l}\text { Conservation } \\
\text { reserve program, } \\
\text { agricultural } \\
\text { margins }\end{array}$ & $\begin{array}{l}\text { Dominated by introduced perennial grass species; other plant species include } \\
\text { colonizing native/introduced forbs, planted trees, and shrubs at low densities }\end{array}$ \\
\hline $\begin{array}{l}\text { Introduced perennial } \\
\text { grassland }\end{array}$ & Pasture & $\begin{array}{l}\text { Dominated by introduced perennial grass species; other plant species include } \\
\text { colonizing native forbs at low densities }\end{array}$ \\
\hline Native grassland & $\begin{array}{l}\text { Palouse prairie } \\
\text { remnants }\end{array}$ & $\begin{array}{l}\text { Dominated by native perennial bunchgrasses; forb diversity is high; shrub and } \\
\text { tree cover varies, characterized by co-dominant native species }\end{array}$ \\
\hline $\begin{array}{l}\text { Seminative } \\
\text { grassland }\end{array}$ & $\begin{array}{l}\text { Degraded prairie } \\
\text { remnants }\end{array}$ & $\begin{array}{l}\text { Disturbed native grasslands; native bunchgrasses usually replaced by invasive } \\
\text { introduced grasses; native forbs and shrubs still prominent components }\end{array}$ \\
\hline Agriculture & $\begin{array}{l}\text { Agricultural } \\
\text { production }\end{array}$ & $\begin{array}{l}\text { Monoculture of important agricultural species in annual rotations, e.g., wheat, } \\
\text { peas, etc.; other species include low densities of weeds and colonizing natives } \\
\text { at field margins }\end{array}$ \\
\hline Agriculture & Hay & $\begin{array}{l}\text { Long-term plantings of alfalfa for green-hay harvest; weeds and colonizing } \\
\text { native species present at field margins }\end{array}$ \\
\hline Forest & $\begin{array}{l}\text { Native forests, } \\
\text { logging }\end{array}$ & $\begin{array}{l}\text { Pinus ponderosa/Pseudotsuga forests; mostly restricted to north-facing slopes } \\
\text { and the eastern Palouse, with a species-rich understory }\end{array}$ \\
\hline Park-grasslands & $\begin{array}{l}\text { Graveyards, golf } \\
\text { courses }\end{array}$ & $\begin{array}{l}\text { Intensively managed introduced grasslands; forb, shrub, and tree species } \\
\text { include native and introduced ornamentals and colonizers }\end{array}$ \\
\hline Mixed woodland & Domestic woodlots & $\begin{array}{l}\text { Orchards and woodlots of native and introduced tree species managed for } \\
\text { firewood, wildlife habitat, and fruit production }\end{array}$ \\
\hline Built & Built_rural & $\begin{array}{l}\text { Structures, parking lots, roads, building sites, and degraded staging areas } \\
\text { outside of city/town limits }\end{array}$ \\
\hline Built & Built_urban & $\begin{array}{l}\text { Structures, parking lot, roads, building sites, and degraded staging areas within } \\
\text { city/town limits }\end{array}$ \\
\hline Pond & $\begin{array}{l}\text { Sewage lagoons, } \\
\text { conservation ponds }\end{array}$ & Lacustrine water bodies, including stock ponds and sewage lagoons \\
\hline
\end{tabular}

Data Center (ICDC) with information gathered during this study to identify locations of these rare species. Because of the sensitive nature of these data, the analyses are discussed generally, but the locations of element occurrences are not shown on maps.

\section{Social data collection}

We selected 90 landowners and other stakeholders residing and/or working in the Palouse area of Latah and Whitman counties to participate in the social component of this study. Using a qualitative case study approach (Stake 1995), we used maximum variation sampling to ensure representation of a range of landowner and stakeholder perceptions (Patton 1990). As seen in Table 4, we recruited initial interview participants based on their primary livelihood identity (Kingsolver 1992, Slater 2001) from formal meetings, workshops, and a review of archival newspaper articles and Web-based searches (Hill 1993). We developed an interview pool using a modified snowball sampling technique (Berg 1995, Bailey 2007) by asking study 
Table 2. Species of special conservation concern on the Palouse.

Conservation status

\begin{tabular}{|c|c|c|c|c|c|}
\hline Scientific name & Common name & Geographic range & Idaho $^{\dagger}$ & Washington & Federal \\
\hline $\begin{array}{l}\text { Cirsium } \\
\text { brevifolium }\end{array}$ & Palouse thistle & $\begin{array}{l}\text { Eastern Oregon, Washington, } \\
\text { northwest Idaho }\end{array}$ & GP3 & Watch list & None \\
\hline Aster jessicae & Jessica's aster & $\begin{array}{l}\text { Washington, Idaho only known } \\
\text { from Palouse region }\end{array}$ & GP2 & Endangered & Candidate \\
\hline $\begin{array}{l}\text { Pyrocomma } \\
\text { liatrifomis }\end{array}$ & $\begin{array}{l}\text { Palouse } \\
\text { goldenweed }\end{array}$ & $\begin{array}{l}\text { Southeastern Washington, } \\
\text { northwest Idaho }\end{array}$ & GP2 & Threatened & $\begin{array}{l}\text { Species of } \\
\text { concern }\end{array}$ \\
\hline Silene spandingii & Spalding's silene & $\begin{array}{l}\text { Eastern Oregon, Washington, } \\
\text { Montana, northern Idaho }\end{array}$ & GP2 & Threatened & Threatened \\
\hline
\end{tabular}

GP3 (Global Priority 3) species have a global rank of G3 or T3, indicating that they are rare but not imperiled. GP2 (Global Priority 2) species have a global rank of G2 or T2, indicating that they are rare and imperiled. Idaho lacks a state endangered species act but uses global and state rankings from the Network of Natural Heritage Programs and Conservation Data Center.

participants to recommend at least one individual who shared their views as well as at least one person who had a different perspective (Patton 1990). Study participants were recruited until theoretical saturation was reached within preliminary analyses (Miles and Huberman 1994).

Many interviewees fit more than one demographic characteristic category, such as a farmer who also serves as a town mayor or a local business owner who could also be highly active in community organizations. Table 5 characterizes the interviewees based on several demographic characteristics developed to illustrate the complexity found in the interview sample profile.

We conducted qualitative, semistructured, face-toface interviews (Miles and Huberman 1994), averaging $1-1.5 \mathrm{~h}$ in duration. Interviews took place in private homes, offices, local businesses, or libraries and began with participants sharing their background and experiences on the Palouse. We then asked them to name and describe three places on the Palouse that were particularly meaningful to them, and to respond to the following questions:
- Can you describe where these places are and what you see when you go there?

- When was the last time you visited these places?

- Have these places changed much since you first started going there? If yes, what do you think about these changes?

- What types of things do you think could be done to care for these places?

Interviews also included a participatory spatial mapping component (Donovan 2007). Using ArcGIS 9 we merged topographic maps for Latah County, Idaho, and Whitman County, Washington, with layers representing primary roads, waterways, towns, and a regional digital elevation model. Using these layers, we created a map template, loaded it onto a laptop computer, and used the template as a base map during the participatory mapping exercise (Fig. 1). After describing their meaningful places, participants drew polygons on the spatial base map indicating the location of those places. We recorded 
Table 3. Biological data used to create species richness maps.

\begin{tabular}{llccccc}
\hline \hline Taxon & Survey method & \multicolumn{3}{c}{ Number of sites } & & Reference \\
\hline \multirow{2}{*}{ Vascular plants } & $\begin{array}{l}\text { Agriculture } \\
\text { plots }\end{array}$ & $\begin{array}{l}\text { Introduced } \\
\text { grassland }\end{array}$ & Forest & Prairie & \\
Vascular plants frame & $2 \times 20$ m transects & 0 & 3 & 0 & 12 & (Hanson et al. 2008) \\
Butterflies & $\begin{array}{l}\text { Variable distance } \\
\text { transects }\end{array}$ & 3 & 6 & 12 & 3 & (Pocewicz 2006) \\
Butterflies & Pollard transects & 3 & 6 & 12 & 3 & (Pocewicz 2006) \\
& & & 4 & 7 & 0 & $\begin{array}{l}\text { (C. Looney, } \\
\text { unpublished } \\
\text { manuscript) }\end{array}$ \\
\hline
\end{tabular}

each participant's mapped place or places as a separate layer and assigned an identifier corresponding with the interview narrative, ensuring that spatial data and narrative data were accurately linked for subsequent analyses.

\section{Data analysis}

\section{Biological data}

We compared native species richness for plants and butterflies among the four landcover types using analysis of variance (ANOVA). Pair-wise comparisons of mean species richness were performed using Tukey's Honestly Significant Difference procedure when significant differences were detected with ANOVA. All statistical analyses were performed using the $\mathrm{R}$ software package for statistical computing (R Development Core Team 2006).

We created an ordinal richness scale to represent species richness for each taxon. We bounded the upper score (10) with the highest sample richness for that taxon and set the lower boundary at 0 . This resulting range was divided into 10 even bins, and mean richness for each cover class was then used to assign an ordinal richness score. The two scores, $i$. e., one for butterflies, one for vascular plants, were then summed to give an indication of overall species richness in each land cover, with a maximum possible ordinal score of 20 and a minimal score of 0 . Scores over 10 were used as a cutoff point to distinguish between land covers with "higher" species richness and "lower" species richness. Analysis of the distribution of the four vascular plant species of conservation concern was based on occurrence records from the WNHP/ICDC databases applied to our land-cover maps to determine the locations of these species in our landcover polygons.

\section{Social data}

We used an iterative approach to analyze the narrative social data, allowing descriptive categories and themes to emerge throughout the research process (Miles and Huberman 1994). We sorted the narrative data into nodes using an NVivo7 computer-aided database system (QSR International, Melbourne, Australia), yielding the identification and analysis of thematic categories used to describe meaningful places.

Narrative data and spatial data were then integrated in a multifaceted database linking narrative themes to each of the mapped places. This approach allowed us to (1) identify places that were meaningful across the range of participants, (2) pinpoint the characteristics shared by meaningful places, and (3) understand the multiple categorized reasons why places were meaningful to the interview participants. 
Table 4. Participant livelihood identity.

\begin{tabular}{lc}
\hline \hline Livelihood identities & Number of participants \\
\hline Public sector $^{\dagger}$ & 14 \\
Private sector-agricultural $^{\ddagger}$ & 29 \\
Private sector-nonagricultural $^{\S}$ & 12 \\
Community organizations $^{\mid}$ & 13 \\
Education community $^{\mathbb{I}}$ & 17 \\
Citizens at large & 15 \\
Total & 90 \\
\hline
\end{tabular}

${ }^{\dagger}$ The public sector includes elected officials, other government-based planners and policy makers, and government agency personnel.

*The agricultural private sector includes producers, ranchers, and business people owning or working for private companies related to agricultural production.

\$The nonagricultural private sector includes entrepreneurs and business people whose work is not based on agricultural production.

lCommunity organizations includes people working at regional or local nonprofit organizations.

IThe education community includes researchers, teachers, and administrators working in Palouse area schools or universities such as the University of Idaho or Washington State University.

\#Citizens at large include retirees and stay-at-home parents.

\section{Interdisciplinary data}

We combined socially meaningful places and landcover layers with high biodiversity to show the overlap between these data sets (Fig. 2). Each overlapping place was coded according to the theme (s) that emerged from the narrative analysis. We limited our analysis to eight major themes based on county-level priorities expressed by planners and policy makers as described in the Latah and Whitman County comprehensive plans and concepts from the bioregional planning framework (Table 6).

We used agglomerative cluster analysis to identify spatial relationships among the eight themes (McGarigal et al. 2000). We calculated Euclidean distance between the eight themes based on a presence-absence matrix of the participant-mapped places associated with each theme. We performed cluster analysis using complete linkage on the resulting distance matrix and examined the resulting dendrogram for evidence of thematic groupings.

\section{RESULTS}

\section{Palouse land cover}

Within the study area, our land-cover data analysis revealed that approximately $72.4 \%$ of the landscape is devoted to agriculture. Approximately 9.2\% comprised introduced perennial grasslands. Forest and prairie cover occupied 11.4 and $1.6 \%$ of the landscape, respectively. Developed areas, ponds, managed parklands, and seminative cover (Table 1) accounted for the remaining $5.6 \%$ of the landscape. Most prairie remnants appeared to be small and relatively inaccessible, typically located deep within agricultural fields. Forest patches tended to 
Table 5. Categories of demographic characteristics of interview participants.

\begin{tabular}{|c|c|c|}
\hline \multirow{2}{*}{$\frac{\text { Demographic characteristics }}{\text { Location of residence }^{\dagger}}$} & \multicolumn{2}{|c|}{ Number of participants in each category } \\
\hline & $\begin{array}{l}\text { Nonrural } \\
46\end{array}$ & $\underset{44}{\text { Rural }}$ \\
\hline Length of residency ${ }^{\ddagger}$ & $\begin{array}{l}\text { New } \\
17\end{array}$ & $\begin{array}{l}\text { Established } \\
63\end{array}$ \\
\hline Gender & $\begin{array}{l}\text { Female } \\
30\end{array}$ & $\begin{array}{l}\text { Male } \\
60\end{array}$ \\
\hline Community involvement ${ }^{\S}$ & $\begin{array}{l}\text { Lower } \\
42\end{array}$ & $\begin{array}{l}\text { Higher } \\
48\end{array}$ \\
\hline Political involvement ${ }^{\prime}$ & $\begin{array}{l}\text { Lower } \\
32\end{array}$ & $\begin{array}{l}\text { Higher } \\
58\end{array}$ \\
\hline
\end{tabular}

${ }^{\dagger}$ Locations within city limits were considered nonrural; outside of city limits, rural.

$\ddagger$ A length of residency of more than $7 \mathrm{yr}$ was considered established; less than $7 \mathrm{yr}$, new, as per selfidentification by participants. In reality, length of residency is a continuum, but is often operationalized as a dichotomous variable in the social science literature (see Smith and Krannich 2000).

§Participants self-identified as having either a low or high level of community involvement. Participants who identified as having low involvement were on average affiliated with $0-2$ community groups, whereas participants who considered themselves to be highly involved averaged 4-6 community group affiliations.

IParticipants who considered themselves to have low political involvement were not affiliated with any local or regional political entities and did not attend regular political meetings. Participants with high political involvement attended regular community meetings and/or held political office.

be larger and associated with parks or private holdings accessible to recreational users.

\section{Biological findings}

Analysis of variance detected significant differences in species richness among the landcover types for both vascular plants $\left(F_{3,39}=100.71\right.$, $P<0.0001)$ and butterflies $\left(F_{3,38}=15.42, P<\right.$ $0.0001)$. Native vascular plant richness was relatively low and not significantly different between agricultural fields and non-native perennial grasslands. Plant richness was significantly greater in native forests and prairie remnants than in agricultural and non-native grassland sites (Table 7). Butterfly richness in prairie remnants was higher than in all other land-cover types $(P<0.0001)$. A nonsignificant trend showed higher butterfly species richness in forests than in agricultural fields or introduced grasslands $(P<0.08)$. Mean richness of vascular plants and butterflies is presented in Table 7.

Based on the combination of ordinal scores for each taxon, forest and prairie have high native species richness (Table 7). Three of the four plant species of special concern were located predominantly on prairie remnants. Palouse goldenweed (Pyrocomma liatrifomis) was strongly associated with prairie remnants and both locally abundant and widespread among remnants. Palouse thistle (Cirsium brevifolium) was also common among prairie remnants as well as open forest. Spalding's catchfly or silene (Silene spandingii), which is a federally listed species, was more rare, although also associated with prairie remnants. The fourth species, Jessica's aster (Aster jessicae), was mostly located in the eastern portion of Latah County and tended to be associated with open forests. None of 
Fig. 2. GIS layers of biologically important areas and socially meaningful places overlaid to show overlapping areas of Importance in study region. (A) Forest patches and prairie remnants within the study area. (B) Participant-mapped places used for interdisciplinary analysis. (C) Overlap of biologically and socially important places within the study area.

A

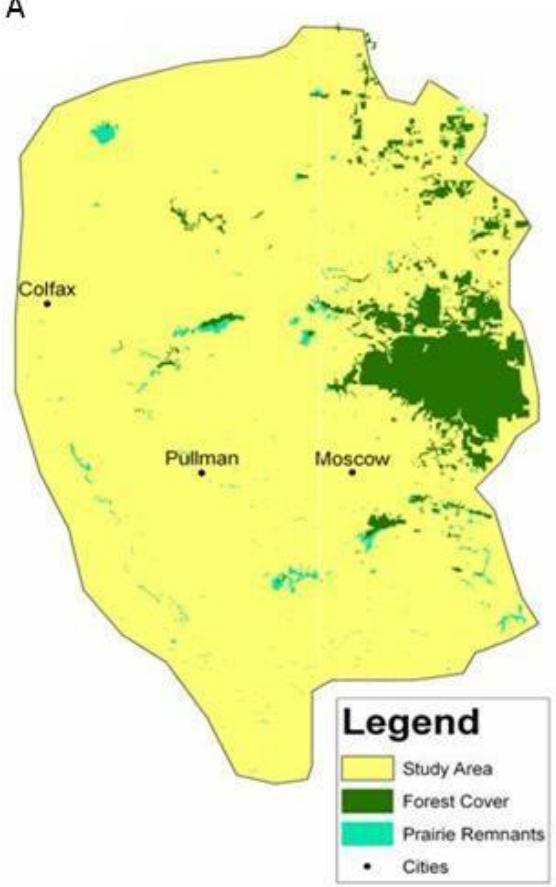

B

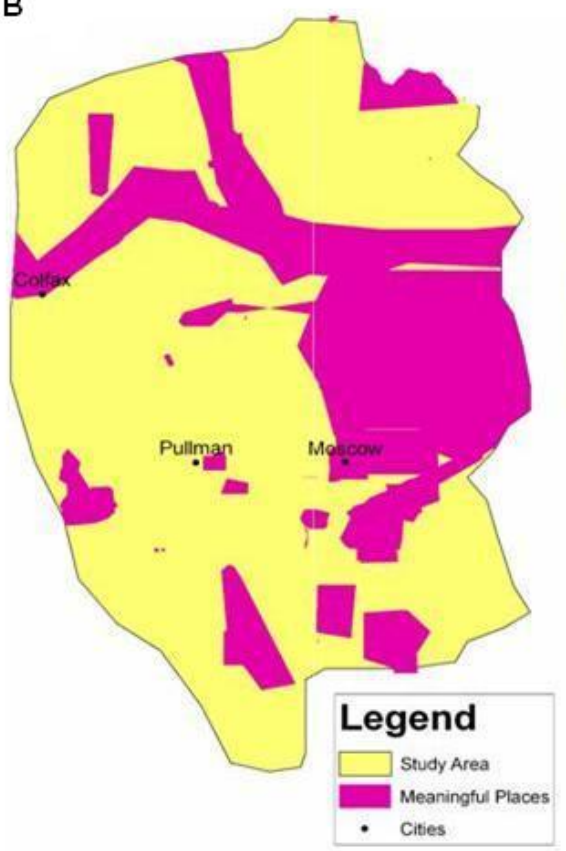

C

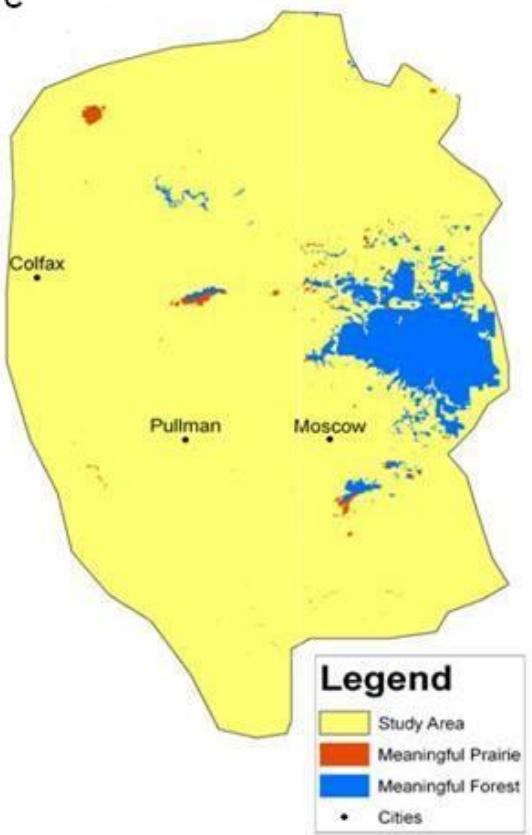

$\hat{\Lambda}$

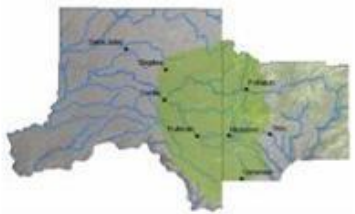

these species was recorded in agricultural fields or introduced perennial grasslands.

\section{Social findings}

Seventy-two of 90 interview participants identified, described, and mapped as many as four meaningful places, creating a total of 154 participant-mapped places. Several interview respondents included multiple reasons from various themes in their meaningful place descriptions. By categorizing these locations based on characteristics that emerged from the narrative analysis, we identified 13 thematic categories from the 401 meaningful place characteristics (Table 6) associated with the 154 individually mapped places. The identified places ranged from the very specific, such as a particular place on a participant's property, to the more general, such as an entire ridgetop.

Eighteen participants were either unable to map their meaningful places on the base map or their mapped places were at a scale too large to be 
Table 6. Operational definitions for meaningful place characteristics.

\begin{tabular}{|c|c|}
\hline Characteristics & Operational definitions \\
\hline Agriculture $^{\dagger}$ & Elements important for agricultural production and practices \\
\hline Attachment ${ }^{\dagger}$ & The emotional ties that make a space into a place (Altman and Low 1992) \\
\hline Natural diversity $^{\dagger}$ & The variety of all levels of life (Gaston and Spicer 2004) \\
\hline Community & People who share experiences and interact in the same places (Chavis et al. 1986) \\
\hline Historical or cultural $^{\dagger}$ & Trends that previously or presently impact or shape society (Jary and Jary 1991) \\
\hline Outdoor recreation & $\begin{array}{l}\text { Activities such as hiking, running, back-country skiing, mushroom picking, bike-riding, hunting, } \\
\text { fishing, motor-boating, and off-road vehicle recreation }\end{array}$ \\
\hline Other recreation & $\begin{array}{l}\text { Activities such as going to the movies, shopping, and attending sporting events and music } \\
\text { concerts }\end{array}$ \\
\hline $\begin{array}{l}\text { Parks and protected } \\
\text { areas }\end{array}$ & $\begin{array}{l}\text { Areas under public or private ownership that are identified as important because they are } \\
\text { preserved and/or managed }\end{array}$ \\
\hline Private ownership ${ }^{\dagger}$ & Areas that are important because they are privately owned, such as homes, offices, and land \\
\hline Sense of place ${ }^{\dagger}$ & Characteristics that define an area and turn a space into a place (Tuan 1974) \\
\hline Topographical features & $\begin{array}{l}\text { Terrain or three-dimensional aspect of an area (Michigan Department of Information Technology } \\
\text { Center for Geographic Information 2007) }\end{array}$ \\
\hline Scenic views ${ }^{\dagger}$ & Vantage points providing visual perceptions of a landscape \\
\hline Water & Areas important as a water source \\
\hline
\end{tabular}

$\dagger$ Indicates socially important meanings used in interdisciplinary analysis.

included in the study. Several of these participants considered the whole landscape meaningful, making it difficult for them to identify specific places within it. This perspective is illustrated by the nonspecific comments of a retired farmer (Respondent 4): "Well, as far as I'm concerned, I think it is one of the greatest places on earth. The Palouse is one of the greatest places."

Other participants were unable to map specific meaningful places but articulated qualities they considered characteristic of such places. For example, one farmer described his meaningful place as "where the tall green grass blows in the wind," and a political leader explained that the "the ocean of rolling hills as far as I can see" was meaningful.
Not to discount the significance of the results, the participant-mapped places that encompassed the entire Palouse were excluded from further analysis because they could not be related to the finerresolution map of native biodiversity.

\section{Interdisciplinary findings: overlap between biologically and socially important areas in the landscape}

One hundred and twenty-four meaningful places overlapped with 113 prairie remnants and 109 forest patches. The meaningful-place characteristic "natural diversity" tended to overlap with the large forest patches and prairie remnants associated with 
Table 7. Mean richness, ordinal scales, and additive ordinal scores used to identify land covers with higher biodiversity values.

\begin{tabular}{|c|c|c|c|c|c|c|}
\hline & $\begin{array}{l}\text { Vascular } \\
\text { plants }\end{array}$ & & Butterflies & & Land cover & $\begin{array}{l}\text { Additive ordinal } \\
\text { score }\end{array}$ \\
\hline $\begin{array}{l}\text { Ordinal } \\
\text { score }\end{array}$ & $\begin{array}{l}\text { Richness } \\
\text { bins }^{\dagger}\end{array}$ & $\begin{array}{l}\text { Land cover/ } \\
\text { mean richness }\end{array}$ & $\begin{array}{l}\text { Richness } \\
\text { bins }\end{array}$ & $\begin{array}{l}\text { Land cover/ } \\
\text { mean } \\
\text { richness }\end{array}$ & Agriculture & 4 \\
\hline 1 & $0-7.7$ & $\mathrm{AG} / 0.0^{c}$ & $0-2.2$ & & $\begin{array}{l}\text { Introduced } \\
\text { perennial grassland }\end{array}$ & 5 \\
\hline 2 & $7.8-15.4$ & IPG/11. $2^{d}$ & $2.3-4.4$ & & Forest & 13 \\
\hline 3 & $15.5-23.1$ & & $4.5-6.6$ & $\begin{array}{l}\mathrm{AG} / 4.6^{b} \\
\mathrm{IPG} / 6.0^{b}\end{array}$ & Prairie & 14 \\
\hline 4 & $23.2-30.8$ & & $6.7-8.8$ & & & \\
\hline 5 & $30.9-38.5$ & & $8.9-11$ & Forest $/ 9.1^{b}$ & & \\
\hline 6 & $38.6-46.2$ & Prairie/46. $1^{b}$ & $11.1-13.2$ & & & \\
\hline 7 & $46.3-53.9$ & & $13.3-15.4$ & & & \\
\hline 8 & $54.0-61.6$ & Forest $/ 60.9^{a}$ & $15.5-17.6$ & Prairie/17. $2^{a}$ & & \\
\hline 9 & $61.7-69.3$ & & $17.7-19.8$ & & & \\
\hline 10 & $69.4-77.0$ & & $19.9-22.0$ & & & \\
\hline
\end{tabular}

We determined richness bins by dividing the sample richness range, e.g. for vascular plants (0-77), into 10 equal intervals.

${ }^{\sharp}$ Superscripts indicate significant differences $(\alpha \leq 0.05)$ between habitats. Means with the same letter are not significantly different.

mountains and ridges in the eastern portion of the Palouse area, although some participants specifically referred to small prairie remnants. For example, one farmer identified a prairie remnant, often called an "eyebrow," located in his field as meaningful particularly because of its natural diversity (Respondent 52): "You go out there, and there are raccoons running along, and you see cougars once in a while, and deer. There are eyebrows in the field where the coyote pups are born in the spring ... I picked up the coyote pups before because, when they first come out, they are just like little puppies."
Although many interview participants described meaningful places in terms of their natural diversity, they also frequently ascribed importance to places encompassing forest and prairie because of other characteristics (Fig. 3). For example, the meaningful place of one rural participant was her home and the surrounding land, which included a prairie remnant. Although this participant included an area of high biodiversity within her mapped place, she ascribed importance to the place based on her experiences and memories, or her sense of attachment to that place (Respondent 18): "My home has got to be on the top. Just the fact that I've 
lived here for the 25 years that I've been here, and that every daughter was born in that room where the piano is. And all our animals ... cats that got too old - they are all buried out in the little round garden back there."

In a variety of contexts, attachment was the meaningful-place characteristic most frequently ascribed to areas of high biodiversity. This characteristic was associated with diverse elements of the biophysical landscape, including cities, the Snake River corridor, individual houses, private land parcels, and the ridgetops and prairie eyebrows associated with land covers of high biodiversity.

Outdoor recreation was a characteristic that interview participants often associated with their meaningful places. Although many of these places included forest and prairie, participants did not necessarily identify biodiversity as an important characteristic of these places. For instance, when describing why Kamiak Butte County Park, which contains a large prairie remnant, was important, one participant limited his response to his recreational experiences there (Respondent 5): "Well, I love Kamiak Butte. I go out there when I want to do a short hike. It's great for hiking. It's not far; it's only like a three-and-a-half-mile hike. But it is nice and enjoyable."

Respondents frequently offered several reasons why a particular place was important to them. Reasons included, but were not limited to, natural diversity. For example, one participant described the cedar grove on Moscow Mountain as especially important, not only because of the diversity of plants and animals but also because of the recreational opportunities associated with the place (Respondent 58): "That's a good place to ride a bicycle. That's a wonderful spot ... and it's also a good place to look for mushrooms."

We used the results from the cluster analysis to decipher the complexity of the relationships among socially meaningful places and their associated characteristics. The resulting dendrogram revealed two clusters: one with characteristics related to historical or cultural values, agriculture, and private land ownership, and another that was important because of outdoor recreation, natural diversity, and scenic views (Fig. 4). The attachment and sense of place themes were connected to both clusters.

The analysis demonstrated that attachment is a meaningful-place characteristic strongly connected with many mapped areas, including those with high biodiversity. Although attachment emerged as a strong theme, it was often associated with other place characteristics. Indeed, most meaningful places were important to participants for multiple reasons, creating a complex framework for understanding the importance of area, place, and community on the Palouse.

Although biological features influenced the social importance of places, several other characteristics were also important for assigning meaning. Interviewees most often identified visible landmarks accessible for outdoor recreation as important for natural diversity, e.g., Moscow Mountain. They also tended to include wildlife, native plants, and ecological functions such as biological corridors as important primarily in the eastern parts of the landscape. As a result, places identified and mapped as important by participants because of natural diversity tended to include prairie remnants and forest patches located on prominent ridgelines and along the eastern, more mountainous borders of the Palouse.

In contrast, the many small prairie remnants located throughout the central and western portion of our study area were less likely to overlap with meaningful places. In most cases, these small remnants harbor species of high conservation value, e.g., Palouse goldenweed, and support high native butterfly and plant richness. The few meaningful places that overlapped with these remnants tended to be associated with the agriculture and attachment themes, rather than the natural diversity theme. Although this result may suggest that public awareness of the existence and importance of prairie remnants is low, it also reflects an opportunity to link prairie conservation with policies that preserve agriculture. This linkage has significant relevance given changing patterns of land use on the Palouse. Because most remaining prairie remnants are privately owned and located within the agricultural matrix, prairie conservation efforts rely on landowner support.

\section{DISCUSSION}

In this study we identified socially and biologically important places on the Palouse and where and why they overlap. Our results provide evidence about the conditions and implications of these important overlaps. Mixed methods approaches that combine qualitative data sets, including studies that relate 
Fig. 3. Spatial maps showing similarity in overlap between (A) outdoor recreation, (B) attachment, and (C) scenic views themes.
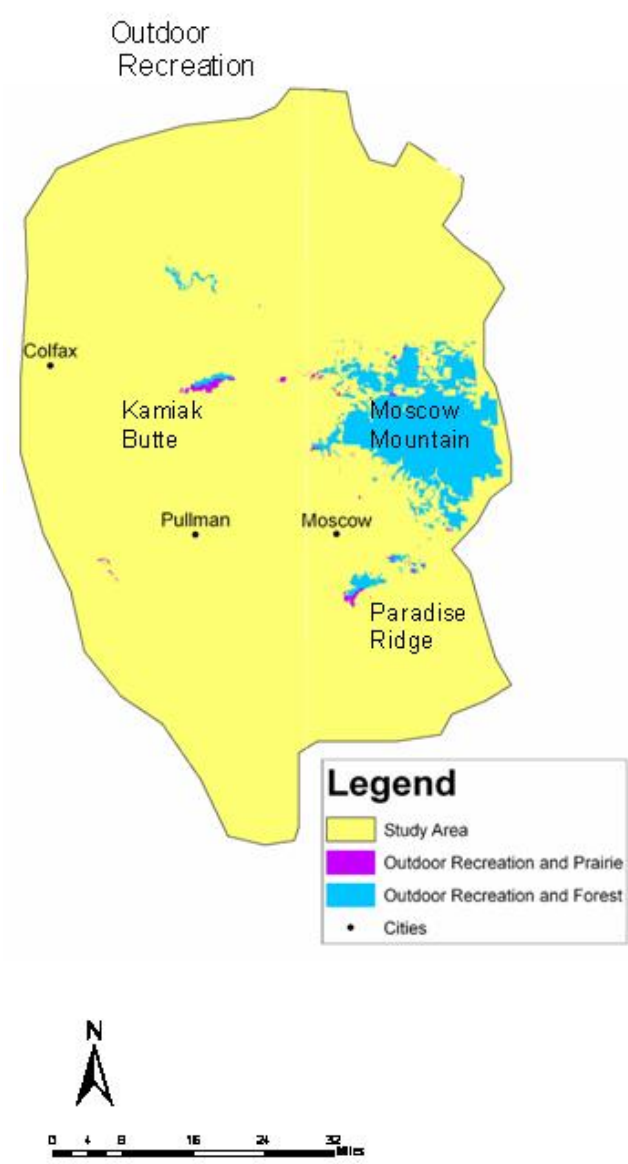
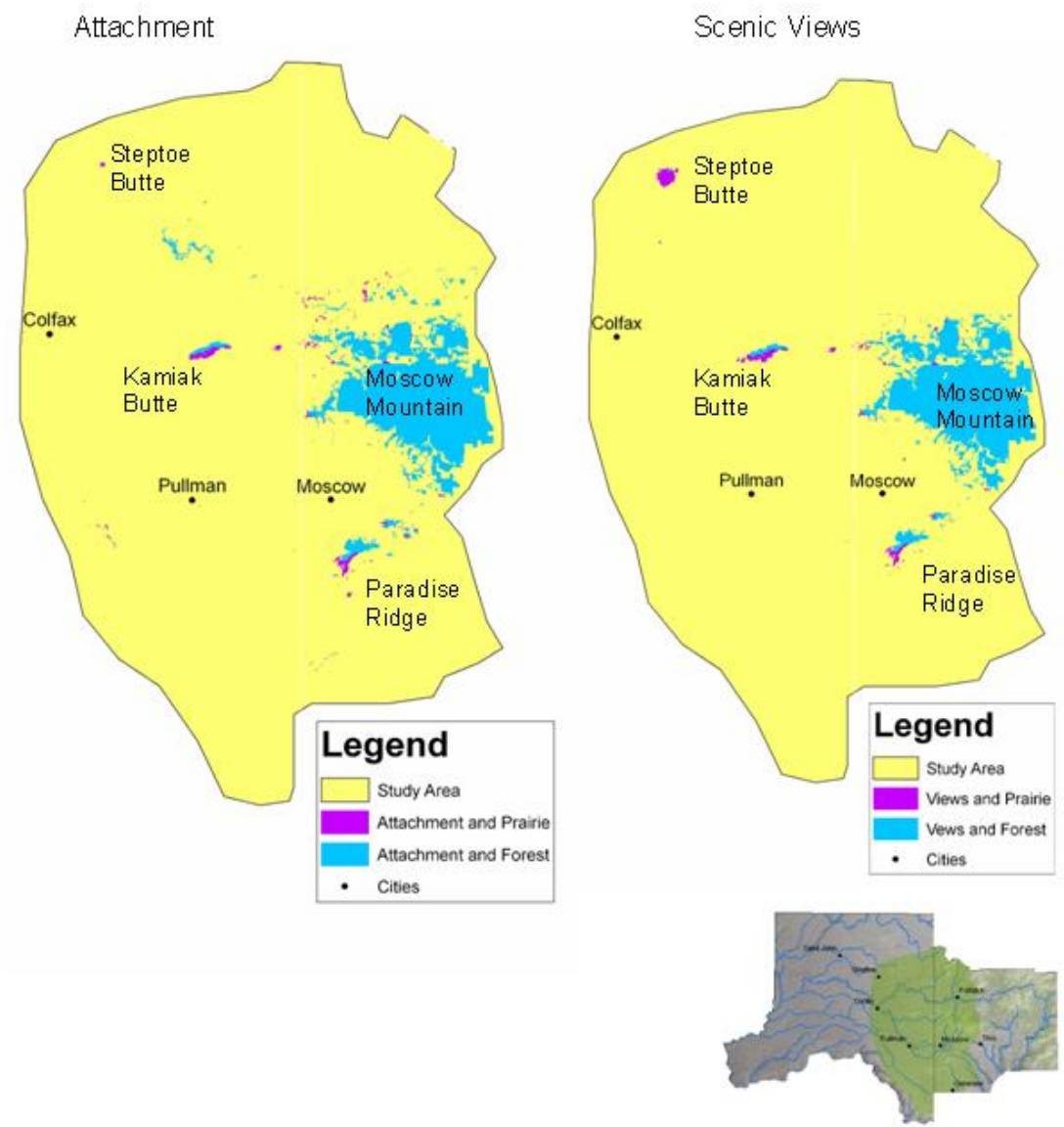

place meanings with GIS, have an increasing range of applications (Creswell 2003, Steinberg and Steinberg 2005). However, our approach extends the literature and applications by using GIS tools to specifically analyze points of intersection between social data derived qualitatively and biological data derived quantitatively. Using this approach allowed us to understand both where and why places of biological importance are or are not socially important to landowners and other stakeholders on the Palouse. The resulting analysis provides new and valuable knowledge for regional planners, showing that species-rich parts of the landscape may be important to stakeholders for reasons in addition to or despite their natural diversity. Understanding the range of social and cultural meanings that participants ascribe to biologically important places provides a more solid foundation for creating effective conservation plans that also reflect stakeholder values and beliefs. The meanings people give to these places reveal deeper social, cultural, economic, and political processes that can inform efforts by planners and policy makers to design socially acceptable land-use planning strategies. 
Fig. 4. Dendrogram of cluster analysis for meaningful place themes from 90 semistructured interviews with Palouse-area landowners and stakeholders. Clusters show distinct groupings of characteristics likely to be associated with particular meaningful places.

\section{Cluster Analysis of Meaningful Place Themes}

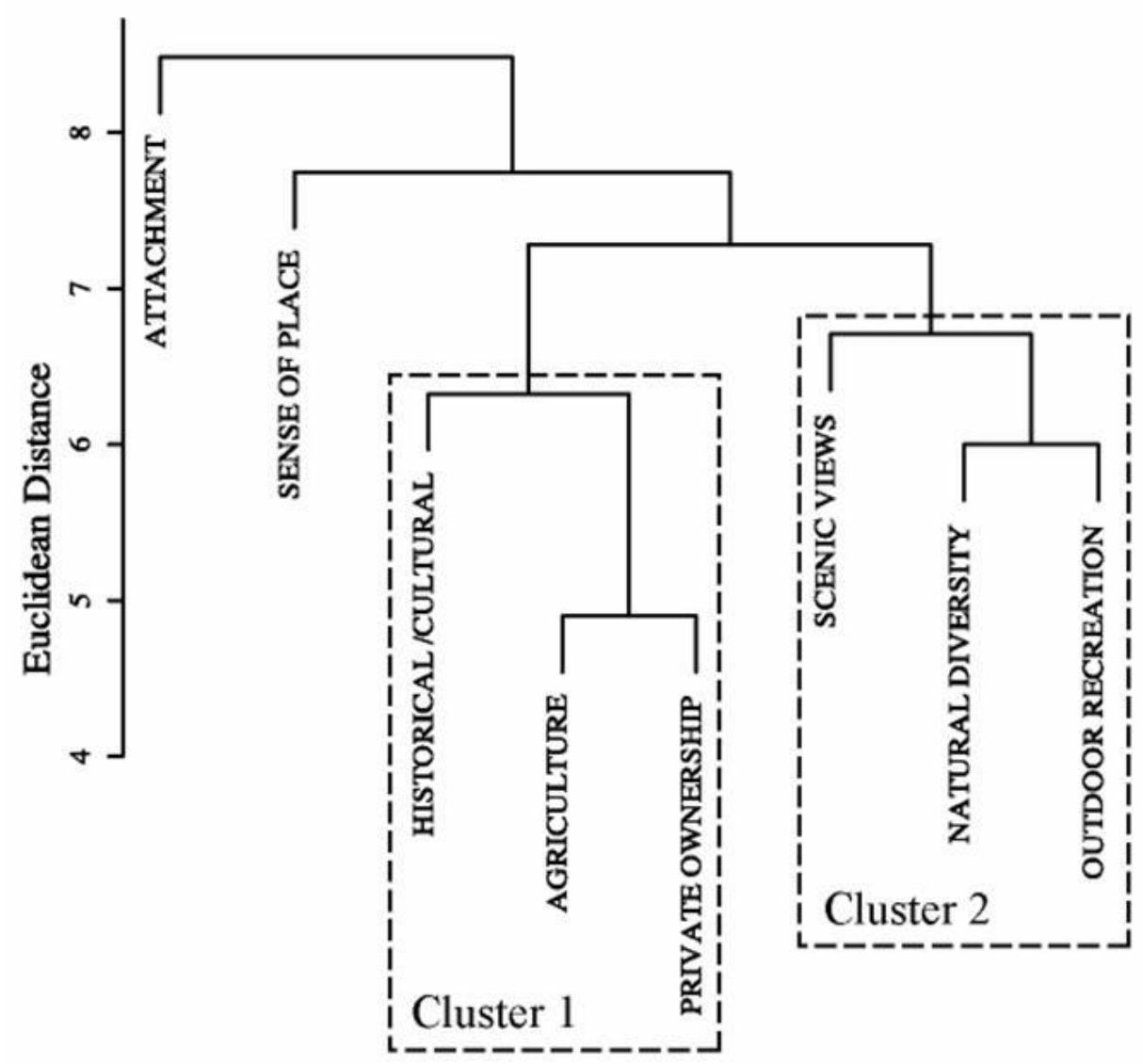

The two clusters visible in the dendrogram (Fig. 4) correspond to the two groupings of associations we described above: (1) themes related to history/ culture, private land ownership, and agriculture, which tend to occur in the western and central portions of the study area, and (2) themes related to scenic views, natural diversity, and outdoor recreation, which predominate in the eastern portion. The meaningful-place characteristics "sense of place" and "attachment" were expressed by many participants in reference to a diversity of places and were connected with both clusters. Both of these patterns suggest that conservation strategies can be targeted specifically to the localized values and meanings ascribed to eastern and western Palouse landscapes. However, the local differences highlighted also emphasize the need for fitting conservation into relevant community contexts that vary by group, place, and other conditions.

The first cluster, which emphasizes historical, cultural, and agricultural themes, reflects a characterization of traditional local communities in the western United States built around production 
livelihoods tied to the land and its resources. In contrast, the second cluster, which includes outdoor recreation, natural diversity, and scenic views, reflects more contemporary phenomena in many localities of the western landscape that are often associated with newcomers and/or landowners who may not have social and political roots in the local communities to which they migrate and/or travel for recreational purposes. Although our analysis does not suggest that the characteristics in these two clusters are mutually exclusive, the patterns highlight multiple, but often overlapping, criteria for how and why people value the same landscapes. In this case, the first cluster symbolizes more of the "Old West," whereas the second indicates more contemporary changes associated with the "New West" (Kemmis 1990). Both clusters also represent aspects of the intensified land-use conflicts often resulting from competing values in the western United States (Nie 2008) as well as the social and political movement to reconcile conflicts with adaptive governance and community-oriented resource management (Brunner and Steelman 2005).

Previous related research revealed an important context for this finding. Jackson-Smith et al. (2005) found a more diverse set of private property orientations among ranchers in Texas and Utah than public policy rhetoric often yields. However, their findings indicated a strong resistance among private landowners to the idea that society has direct interests in land stewardship on private lands, including cases of damage to the natural environment. As such, an important gap may remain in connecting the sense of stewardship of production-oriented private landowners to public sentiments about the social goods sought from the same landscapes.

In contrast to Jackson-Smith et al. (2005), Yung and Belsky (2007) provide the insight that, at the local level, private property ownership in the western United States can also carry social obligations such as hunting rights, access for the local community, etc. Their study identified differences between longterm and newer landowners in terms of how well they understood nuances about localized boundaries. Given the findings within our cluster analysis, the fragmentation of the Palouse landscape by rural residential development will continue to exacerbate the need for more integrated planning by local municipalities (Shumway and Otterstrom 2001, Sutton and Day 2004) to account for custom and culture at the community level (Wulfhorst et al. 2006). In this regard, our results illustrate how "attachment" and "sense of place" correlate to both clusters, indicating a range of beliefs and sentiments about the importance of the same places, for overlapping reasons, across multiple groups within the landscape.

Understanding how these themes are inter-related and connected to the landscape has implications for conservation planning in this diverse landscape. The eastern Palouse may best be conserved by planning efforts that emphasize views, sense of place, and outdoor recreation. Appealing to the concern for natural diversity may also be effective, including initiatives for rare native species like the Palouse goldenweed or the giant Palouse earthworm. However, this approach may work better for conserving forested and high-elevation grasslands, because these were the areas most commonly identified as meaningful by participants.

In contrast, in the western portion of the Palouse, meanings were more likely to be associated with Cluster 1, i.e., agriculture, private land ownership, and attachment. This result indicates that prairie remnants may best be conserved there on an individual basis, perhaps by using an incentivebased or steward partnership program. Current agricultural conservation programs may also achieve biodiversity goals by protecting prairie remnants within farm boundaries from conversion to other land uses. On the other hand, a conservation focus that emphasizes threatened species alone could be viewed as a threat by advocates for private land rights (James 2002) and be less successful.

Because most remnants are located on private land, public support is necessary to ensure the conservation of Palouse Prairie (Russell and Harshbarger 2003). As in other regions, many landowners on the Palouse identify themselves as resource stewards (Carlson et al. 1994, James 2002). However, when faced with the perceived dilemma of conserving resources over maintaining private land rights and financial well-being, landowners may hedge on giving priority to biodiversity (James 2002). Thus, understanding landowner and stakeholder perspectives and the intrinsic value they place on areas of high biodiversity is critical to the implementation of successful conservation plans. 


\section{CONCLUSIONS}

Conservation plans that incorporate social criteria for valuing our natural heritage can garner more support than those based solely on biological criteria (Thayer 2003). Perhaps even more important, precisely because social criteria can link to ecological parameters such as biodiversity, they may have the effect of reducing conflict by virtue of (1) integrating multiple dimensions and definitions of management situations, (2) creating more robust outcomes, and (3) acknowledging the integrity of both community and scientific viewpoints (Brunner and Steelman 2005). Identifying the sense of place and attachment to place that can catalyze conservation-minded behavior and acceptance of conservation policy by the public is relevant and integral to sustainable planning (Thayer 2003). Although challenging in an analytical sense, our approach of integrating qualitative stakeholder mapping with indices of biological diversity in a spatially explicit manner revealed some overarching trends in the spatial relationship of local values and biodiversity resources. Such an analysis can supplement and improve the more traditional planning view of social, economic, and biological values as often inherently in conflict with each other (Campbell 1996). Thayer (2003) advocates addressing the complexities related to these three areas directly and looking for planning solutions that link these realms, rather than approaching each separately. This approach is facilitated by collaborating with stakeholders to set planning goals and remaining flexible in the implementation and conception of those goals (e.g., Carr et al. 1998, Wondolleck and Yaffee 2000).

Our study builds upon these insights by assessing landscape elements based on their socially perceived importance, apart from whatever biodiversity conservation value these elements may have. GIS tools can help obtain participatory input for conservation planning (Talen 2000, Gonzalez 2002, Russell and Harshbarger 2003). Our approach differed from these prior studies in that we used GIS to combine participant-derived maps of socially important areas with a layer of biological diversity derived from direct sampling in the landscape. More recent analyses have combined GIS layers of social and ecological metrics in interdisciplinary efforts to identify hotspots in which conservation needs and social importance appear to coincide (Siniscalchi et al. 2006, Alessa et al. 2008). Our approach is similar, but differs from these by overlaying biodiversity estimates with social data gathered using a semistructured process that is less restrictive than direct surveys with regard to the information obtained about social importance. Using this approach, we have identified attitudes within the local citizenry that could not only support but also expedite conservation efforts in specific parts of the Palouse landscape. Although we did not directly measure methodological effects, field observations indicate that this method may also empower participants by enabling them to convey their knowledge of the landscape as a participatory endeavor (Talen 2000, Higgins 2004). We submit that such an approach is applicable wherever conservation efforts are required in humandominated fragmented landscapes, a prevalent condition worldwide (Pretty 1995).

Our approach of linking qualitative perceptions of the landscape with biodiversity hotspots may diversify the ways in which county planners garner support for conservation efforts. For example, the perception of the Palouse Prairie as an important ecological and cultural resource has increased in recent years (Donovan 2007), which creates the opportunity for adaptive and novel conservation approaches based on the convergence of different values, e.g., biodiversity and pioneer history, upon the same physical resource. This also exemplifies the dynamic nature of local demographics, perceptions, and biological conditions in the American West. This dynamism requires an approach to resource management that is both adaptive and collaborative (Dietz et al. 2003, Folke et al. 2005), a process facilitated by understanding the relationships between the landscape and the values revealed in our study. The in-depth interviews we used add nuance to the process of building collaborative networks by revealing broad themes in values, as exemplified by our cluster analysis, as well as how the rationale for those values may connect stakeholders. For example, most of the small prairie remnants on deep soils are located within the agricultural matrix, which was only weakly associated with biodiversity values in our study. Nonetheless, these remnants are valuable to conservation biologists and prairie activists even though they are located in a part of the landscape associated with additional economic, specifically agricultural, production and social, i.e., farming life-style, values. One concern producers and conservationists share in the region is the control of invasive weeds as a threat to production and prairie 
species, respectively. A potential collaboration in the region consistent with opportunities for adaptive management action could be to allow prairie conservation groups to access privately owned remnants for noxious weed control and restoration activities, which should benefit both groups. This might be best accomplished in a citizen-led collaboration, because government-led actions have generated distrust in some cases (Nie 2008).

Throughout this study, local land-use planners and conservation organizations on the Palouse have expressed support and interest in our results and methods, and they are now including this information in their ongoing planning exercises. The Latah County Planning and Zoning Commission is currently conducting stakeholder workshops to further understand human perceptions of the landscape and the need to revise the county's comprehensive plan. The Commission also asked us to present our results and recommendations. Because many of these individuals also served as participants in the study, their perspectives regarding regional planning efforts are embedded in the findings. The study reflects planner and citizen perspectives and therefore can help to promote the adoption of the resulting plans in a region in which many view land-use regulation with suspicion. Whether conservation of biologically important areas can ultimately be achieved by appealing to other values remains to be seen, but the results of this study and its positive reception by local officials is encouraging. In this context, we offer several practical recommendations for policy makers and planners that we derive from this study:

- Create the ways and commit the means necessary to understand landscapes from both biophysical and social environment points of view. Integrating these points of view can reveal patterns informative for effective conservation policy strategies.

- Investigate overlaps between biologically and socially important characteristics, because connecting divergent values may provide the common ground needed to avoid or overcome obstacles to broadly shared goals for promoting landscape quality and stewardship.

- Design participatory techniques to find out more about what places local residents are attached to, and why. Inform other stakeholders and policy makers of these views as part of conservation policy development.

The approach we outline has two potential limitations and challenges. First, its feasibility will depend upon the availability and resolution of biological data. Complete biodiversity surveys will typically be impractical and prohibitively costly. Alternatively, remote sensing to estimate potential biodiversity may be feasible in some settings, e.g., spectral correlates of net primary productivity (Alessa et al. 2008). On the Palouse, however, we determined that spectral data did not provide any useful information about biodiversity, necessitating the combination of empirical sampling and the visual land-use classifications that we used. This is likely true in other settings. Our analysis therefore relied on indicator taxa. Sampling methodologies necessarily differed for each taxon, so that the data were collected at somewhat different spatial scales and sampling intensities. Given land-use changes, indicator species may vary over time, creating a need for systematic sampling across the landscape. Future sampling and monitoring of Palouse Prairie remnants could be conducted by local not-for-profit and citizens' organizations as part of restoration and conservation activities. Second, semistructured interviews yield rich data about human perceptions, but all of these data do not readily inform spatially explicit maps of social valuation of the landscape. Nonetheless, we found that the in-depth explanatory information gained through the semistructured, face-to-face interview outweighed this limitation. Practitioners will need to determine whether the semistructured or more directed survey approaches are most appropriate for generating GIS layers as indicators of social importance. Both have relevance within their respective appropriate settings. For example, using an exploratory approach during the interview process allowed us to better understand the range of meaningful places for stakeholders and allowed interview participants to reveal as much or as little as they wished about these places. Planners and policy makers can use the rich data generated through this study to develop more focused questions that will be useful in creating conservation plans that accurately reflect the social value of native biodiversity.

Although challenging, coordination of social and biological data collection is critical to this method. The best results may be achieved in an adaptive 
context, using iterative steps in which maps such as those generated in our study are then used as guides to direct resources for obtaining further social and biological data with the appropriate resolution.

Responses to this article can be read online at: http://www.ecologyandsociety.org/voll4/iss1/art9/responses/

\section{Acknowledgments:}

The authors would like to thank the study participants, landowners, and other stakeholders who made this research possible. This study was funded by National Science Foundation Integrative Graduate Education and Research Traineeship Program (IGERT) grant number 0114304.

\section{LITERATURE CITED}

Alessa, L., A. Kliskey, and G. Brown. 2008. Social-ecological hotspots mapping: a spatial approach for identifying coupled social-ecological space. Landscape and Urban Planning 85:27-39.

Altman, I., and S. M. Low, editors. 1992. Place attachment. Plenum Press, New York, New York, USA.

Bailey, C. A. 2007. A guide to qualitative field research. Second edition. Pine Forge Press, Thousand Oaks, California, USA.

Bailey, R. G. 2003. Ecoregion-based design for sustainability. Springer-Verlag, New York, New York, USA.

Berg, B. L. 1995. Qualitative research methods for the social sciences. Second edition. Allyn and Bacon, Boston, Massachusetts, USA.

Black, A. E., E. Strand, P. Morgan, J. M. Scott, R. G. Wright, and C. Watson. 2000. Biodiversity and land-use history of the Palouse bioregion: preEuropean to present. Chapter 10 in T. D. Sisk, editor. Land use history of North America. U.S. Geological Survey, Washington, D.C., USA. Available online at: http://biology.usgs.gov/luhna/chap10.html.
Blumenthal, D. M., N. R. Jordan, and E. L. Svenson. 2003. Weed control as a rationale for restoration: the example of tallgrass prairie. Conservation Ecology 7(1): 6. [online] URL: http:/ /www.consecol.org/vol7/iss 1/art6/.

Boothby, J. 2000. An ecological focus for landscape planning. Landscape Research 25:281-289.

Brown, G., and C. Raymond. 2007. The relationship between place attachment and landscape values: towards mapping place attachment. Applied Geography 27:89-111.

Brunner, R. D., and T. A. Steelman. 2005. Beyond scientific management. Pages 1-46 in R. D. Brunner, T. A. Steelman, L. Coe-Juell, C. M. Cromley, C.M. Edwards, and D. W. Tucker, editors. Adaptive governance: integrating science, policy, and decision making. Columbia University Press, New York, New York, USA.

Buckland, S. T., D. R. Anderson, K. P. Burnham, J. L. Laake, D. L. Borchers, and L. Thomas. 2004. Advanced distance sampling. Oxford University Press, New York, New York, USA.

Caldwell, H. H. 1961. The Palouse in diverse disciplines. Northwest Science 35:115-121.

Callaham, M. A., and J. M. Blair. 1991. Influence of differing land management on the invasion of North American tallgrass prairie soils by European earthworms. Pedobiologia 43:507-512.

Campbell, S. 1996. Green cities, growing cities, just cities? Urban planning and the contradictions of sustainable development. Journal of the American Planning Association 62(3):296-311.

Carlson, J. E., B. Schnabel, C. E. Beus, and D. A. Dillman. 1994. Changes in the soil conservation attitudes and behaviors of farmers in the Palouse and Camas prairies: 1976-1990. Journal of Soil and Water Conservation 49:493-500.

Carr, D., S. Selin, and M. Schuett. 1998. Managing public forests: understanding the role of collaborative planning. Environmental Management 5:767-776.

Chavis, D. M., J. H. Hogge, D. W. McMillan, and A. Wandersman. 1986. Sense of community 
through Brunswick's lens: a first look. Journal of Community Psychology 14:24-40.

Cheng, A. S., L. E. Kruger, and S. E. Daniels. 2003. "Place" as an integrating concept in natural resource politics: propositions for a social science research agenda. Social and Natural Resources 16:87-104.

Creswell, J. W. 2003. Research design: qualitative, quantitative, and mixed methods approaches. Second edition. Sage Publications, Thousand Oaks, California, USA.

Daubenmire, R. F. 1942. An ecological study of the vegetation of southeastern Washington and adjacent Idaho. Ecological Monographs 1:53-79.

Daubenmire, R. F. 1970. Steppe vegetation of Washington. Washington Agricultural Experiment Station Technical Bulletin No. 62. Washington State University, Pullman, Washington, USA.

Dickens, S. J. M., F. Gerhardt, and S. K. Collinge. 2005. Recreational portage trails as corridors facilitating non-native plant invasions of the Boundary Waters Canoe Area Wilderness (USA). Conservation Biology 19:1653-1657.

Dietz, T., E. Ostrom, and P. Stern. 2003. The struggle to govern the commons. Science 302:1907-1912.

Donovan, S. 2007. The Palouse: a bioregional approach for assessing sense of place. Dissertation. University of Idaho, Moscow, Idaho, USA.

Duffin, A. P. 2005. Vanishing earth: soil erosion in the Palouse, 1930-1945. Agricultural History 79:173-192.

Fargione, J. E., and D. Tilman. 2005. Diversity decreases invasion via both sampling and complementarity effects. Ecology Letters 8:604-611.

Farina, A. 2000. Integrating ecology and economics. BioScience 50:313-320.

Fender, W. M., and D. McKey-Fender. 1990. Oligochaeta: Megascolecidae and other earthworms from western North America. Pages 357-378 in D. L. Dindal, editor. Soil biology guide. Wiley, New York, New York, USA.

Folke, C., T. Hahn, P. Olsson, and J. Norberg. 2005. Adaptive governance of social-ecological knowledge. Annual Review of Environment and Resources 30:441-473.

Forsyth, D. J., and N. D. Westcott. 1994. Carbofuran residues in grasshoppers and vegetation from aerially sprayed prairie pastures-potential effects on wildlife. Environmental Toxicology and Chemistry 13:299-306.

Gaston, K. J., and J. I. Spicer. 2004. Biodiversity: an introduction. Second edition. Blackwell, Malden, Massachusetts, USA.

Gonzalez, R. M. 2002. Joint learning with GIS: multi-actor resource management. Agricultural Systems 73:99-111.

Greider, T., and L. Garkovich. 1994. Landscapes: the social construction of nature and the environment. Rural Sociology 59:1-24.

Gurr, G. M., S. D. Wratten, and J. M. Luna. 2003. Multi-function agricultural biodiversity: pest management and other benefits. Basic and Applied Ecology 4:107-116.

Hanson, T., Y. Sanchez de Leon, J. JohnsonMaynard, and S. Brunsfeld. 2008. The influence of soil and site characteristics on Palouse prairie plant communities. Western North American Naturalist 68:231-240.

Herring, M. 1999. Introduction. Pages 1-8 in K. N. Johnson, F. Swanson, M. Herring, and S. Greene, editors. Bioregional assessments: science at the crossroads of management and policy. Island Press, Washington, D.C., USA.

Higgins, L. 2004. Video as a tool for communitycentered research. Community-Centered Research Series: Measuring What Matters (CCR4). Available online at: http://extension.usu.edu/files/publications/ publication/pub 6498387.pdf.

Hill, M. R. 1993. Archival strategies and techniques. Sage, Thousand Oaks, California, USA.

Hooper, D. U., F. S. Chapin, III, J. J. Ewel, A. Hector, P. Inchausti, S. Lavorel, J. H. Lawton, D. Lodge, M. Loreau, S. Naeem, B. Schmid, H. Setää, A. J. Symstad, J. Vandermeer, and D. A. Wardle. 2005. Effects of biodiversity on ecosystem functioning: a consensus of current knowledge and needs for future research. Ecological Monographs 75:3-35. 
Jackson-Smith, D., U. Kreuter, and R. S. Krannich. 2005. Understanding the multidimensionality of property rights orientations: evidence from Utah and Texas ranchers. Society and Natural Resources 18:587-610.

James, S. M. 2002. Bridging the gap between private landowners and conservationists. Conservation Biology 16:269-271.

Jary, D., and J. Jary. 1991. The HarperCollins dictionary of sociology. HarperCollins, New York, New York, USA.

Kemmis, D. 1990. Community and the politics of place. University of Oklahoma Press, Norman, Oklahoma, USA.

Kingsolver, A. E. 1992. Contested livelihoods: "placing" one another in Cedar, KY. Anthropology Quarterly 65:128-136.

Kleijn, D., and G. I. J. Snoeijing. 1997. Field boundary vegetation and the effects of agrochemical drift: botanical change caused by low levels of herbicide and fertilizer. Journal of Applied Ecology 34:1413-1425.

Krauss, J., I. Steffan-Dewenter, and T. Tscharntke. 2003. How does landscape context contribute to effects of habitat fragmentation on diversity and population density of butterflies? Journal of Biogeography 30:889-900.

Kruess, A., and T. Tscharntke. 2000. Species richness and parasitism in a fragmented landscape: experiments and field studies with insects on Vicia sepium. Oecologia 122:129-137.

Latah County Planning and Zoning Commission. 2004. Meeting minutes (October 26). Available online at: http://www.latah.id.us/Comm/PlanZone/ Plan/2004 1026 Minutes.pdf.

Laughlin, D. C. 2003. Geographic distribution and dispersal mechanisms of Bouteloua curtipendula in the Appalachian Mountains. American Midland Naturalist 149:268-281.

Lichthardt, J., and R. K. Moseley. 1997. Status and conservation of the Palouse grassland in Idaho. Idaho Department of Fish and Game. Boise, Idaho, USA.
Luzar, E. J., and A. Diagne. 1999. Participation in the next generation of agricultural conservation policies: the role of environmental attitudes. Journal of Socio-Economics 3:11-27.

Marino, P. C., and D. A. Landis. Effect of landscape structure on parasitoid diversity and parasitism in agroecosystems. Ecological Applications 6:276-284.

Maron, J., and M. Marler. 2007. Native plant diversity resists invasion at both low and high resource levels. Ecology 88:2651-2661.

McGarigal, K., S. Cushman, and S. Stafford. 2000. Multivariate statistics for wildlife and ecology research. Springer-Verlag, New York, New York, USA.

McGeoch, M. A. 1998. The selection, testing and application of terrestrial insects as bioindicators. Biological Reviews 73:181-201.

McHarg, I. L. 1969. Design with nature. Natural History Press, Garden City, New York, USA.

McKone, M. J., K. K. McLauchlan, E. G. Lebrun, and A. C. McCall. 2001. An edge effect caused by adult corn-rootworm beetles on sunflowers in tallgrass prairie remnants. Conservation Biology 15:315-1324.

Michigan Department of Information Technology Center for Geographic Information. 2007. Frequently asked questions for geographic information systems (GIS) — what is topography? [online] URL: http://www.michigan.gov/cgi/0,1607 ,7-158-14767-31893--F,00.html.

Miles, M. B., and A. M. Huberman. 1994. An expanded source book, qualitative data analysis. Second edition. Sage, Thousand Oaks, California, USA.

Nie, M. 2008. The governance of western public lands: mapping its present and future. The University Press of Kansas, Lawrence, Kansas, USA.

Norton, D. A. 2000. Conservation biology and private land: shifting the focus. Conservation Biology 14:1221-1223.

Noss, R. F., F. T. Laroe III, and J. M. Scott. 1995. 
Endangered ecosystems of the United States: a preliminary assessment of loss and degradation. Biological Report No. 28. U.S. National Biological Service, Washington, D.C., USA.

Orr, W. N., and E. L. Orr. 2002. Geology of the Pacific Northwest. Second edition. Waveland Press, Long Grove, Illinois, USA.

Patton, M. Q. 1990. Qualitative evaluative and research methods. Sage, Thousand Oaks, California, USA.

Pocewicz, A. 2006. Modeling landscape change and evaluating ecological effects of landscape composition and configuration in Northern Idaho. Dissertation. University of Idaho, Moscow, Idaho, USA.

Pollard, E., and T. J. Yates. 1993. Monitoring butterflies for ecology and conservation; the British butterfly monitoring scheme. Springer-Verlag, New York, New York, USA.

Pokorny, M. L., R. L. Sheley, C. A. Zabinski, R. E. Engel, T. J. Svejcar, and J. J. Borkowski. 2005. Plant functional group diversity as a mechanism for invasion resistance. Restoration Ecology 13:448-459.

Pretty, J. N. 1995. Participatory learning for sustainable agriculture. World Development 23:1247-1263.

R Development Core Team. 2006. $R$ : a language and environment for statistical computing. $\mathrm{R}$ Foundation for Statistical Computing, Vienna, Austria.

Ricketts, T., E. Dinerstein, D. Olson, C. Loucks, W. Eichbaum, K. Kavanagh, P. Hedao, P. Hurley, K. Carney, R. Abell, and S. Walters. 1997. A conservation assessment of the terrestrial ecoregions of North America. Island Press, Washington, D.C., USA.

Riebsame, W. E. 1998. Ranching a changing landscape: development, perception, and the political ecology of the Western Range. Pages 157-172 in K. Hess Jr. and J. A. Baden, editors. Writers on the range: western writers exploring the changing face of the American West. University of Colorado, Boulder, Colorado, USA.
Russell, D., and C. Harshbarger. 2003. Ground work for community-based conservation. AltaMira Press, Walnut Creek, California, USA.

Sánchez de León, Y., and J. Johnson-Maynard. 2008. Dominance of an invasive earthworm in native and non-native grassland ecosystems. Biological Invasions. Available online at: http://dx. doi.org/10.1007/s10530-008-9347-6.

Scheuerman, R. J. 2003. Palouse country: it's land and it's people. McGregor, Walla Walla, Washington, USA.

Shumway, J. M., and S. M. Otterstrom. 2001. Spatial patterns of migration and income change in the Mountain West: the dominance of servicebased, amenity-rich counties. Professional Geographer 53:492-502.

Siniscalchi, J. M., C. D. Pierrskalla, S. W. Selin, and D. Palmer. 2006. Mapping social change: a visualization method used in the Monogahela National Forest. Society and Natural Resources 19:71-78.

Slater, R. 2001. De-industrialisation, multiple livelihoods and identity: tracking social change in Qwaqwa, South Africa. Journal of Contemporary African Studies 19:81-92.

Smith, M.S., and R. S. Krannich. 2000. "Culture clash" revisited: newcomer and longer-term residents' attitudes toward land use, development, and environmental issues in rural communities in the Rocky Mountain West. Rural Sociology 65:396-421.

Stake, R. E. 1995. The art of case study research. Sage, Thousand Oaks, California, USA.

Steffan-Dewenter, I., and T. Tscharntke. 2002. Insect communities and biotic interactions on fragmented calcareous grasslands-a mini review. Biological Conservation 104:275-284.

Steinberg, S. J., and S. L. Steinberg. 2005. Geographic information systems for the social sciences: investigating space and place. Sage, Thousand Oaks, California, USA.

Steiner, F. 1991. The living landscape: the ecological approach to landscape planning. Second 
edition. McGraw-Hill, New York, New York, USA.

Suding, K. N., S. L. Collins, L. Gough, C. Clark, E. E. Cleland, K. L. Gross, D. G. Milchunas, S. Pennings, and F. S. Chapin III. 2005. Functionaland abundance-based mechanisms explain diversity loss due to $\mathrm{N}$ fertilization. Proceedings of the National Academy of Sciences of the United States of America 102:4387-4392.

Sutton, P. D., and F. A. Day. 2004. Types of rapidly growing counties of the U.S., 1970-1990. Social Science Journal 41:251-265.

Talen, E. 2000. Bottom-up GIS. Journal of the American Planning Association 66:279-295.

Thayer, R. L. 2003. Lifeplace: bioregional thought and practice. University of California Press, Berkeley, California, USA.

Theobald, D. M., and N. T. Hobbs. 1998. Forecasting rural land use change: a comparison of regression- and spatial transition-based models. Geographical and Environmental Modeling 2:65-82.

Theobald, D. M., and N. T. Hobbs. 2002. A framework for evaluating land use planning alternatives: protecting biodiversity on private land. Conservation Ecology 6:5. [online] URL: http://ww w.consecol.org/vol6/iss 1/art5/.

Thies, C., I. Steffan-Dewenter, and T. Tscharntke. 2003. Effects of landscape context on herbivory and parasitism at different spatial scales. Oikos 101:18-25.

Tuan, Y. F. 1974. Topophilia: a study of environmental perception, attitudes, and values. Prentice-Hall, Englewood Cliffs, New Jersey, USA.

Weddell, B., and J. Lichthardt. 1998. Identification of conservation priorities for and threats to Palouse grassland and Canyon grassland remnants in Idaho, Washington, and Oregon. Idaho Bureau of Land Management Technical Bulletin No.98-13. Idaho Bureau of Land Management, Boise, Idaho, USA.

Wondolleck, J. M., and S. L. Yaffee. 2000. Making collaboration work: lessons from innovation in natural resource management. Island Press, Washington, D.C., USA.
Wulfhorst, J. D., N. R. Rimbey, and T. Darden. 2006. Sharing the rangelands, competing for sense of place. American Behavioral Scientist 50:166-186.

Yung, L., and J. M. Belsky. 2007. Private property rights and community goods: negotiating landowner cooperation amid changing ownership on the Rocky Mountain Front. Society and Natural Resources 20:689-703. 